\title{
ARTICLE
}

\section{Assessment of Eco-geomorphological potential of Mongolia}

\author{
Bayanjargal Bumtsend*, Purevsuren Munkhtur and Avirmed Erdenedalai \\ Division of Physical Geography, Institute of Geography and Geoecology, \\ Mongolian Academy of Sciences, Ulaanbaatar, Mongolia.
}

ARTICLE INFO: Received: 04 Aug, 2020; Accepted: 29 Sep, 2020

\begin{abstract}
The eco-geomorphological analysis includes the impact assessment of relief under various ecosystem conditions in as much relief has various ecological roles, both direct and indirect. Rising elevation above sea level is mostly influenced by climate indirectly leading to reduced air pressure, oxygen deficiency, reduction of air temperature, excessive solar radiation, and creation of strong wind. The depth of relief dissection of the bumpy surface of mountainous areas created by floods and mudflows, and the depth of the bumpy surface increases energy consumption and poses risks during mountain climbing, and also has negative economic implications if economic activities are undertaken in such terrain. On the other hand, mountainous landscapes have a specific impact on human well-being and also have considerable potential for promoting tourism. Although, in the steppe environment, relief dissection increases the unique features of the landscape and increases the potential of tourism in other respects, however, it is assessed negatively to a large extent. The nature of corelationship between and the interdependence of the terrestrial surface and population, terrestrial surface and livestock, terrestrial surface and agriculture, which are significant in the study into the inter-relationship between environment and human society, was assessed and determined, and the relevant conclusion was drawn.
\end{abstract}

Keywords: human habitat; population; animal husbandry; agriculture; potential assessment;

\section{INTRODUCTION}

The concept of eco-geomorphology was first used in science by a British geomorphologist Donald Coates in the early 1970s, while another scientist T.G. Runova proposed a consolidated idea of surface assessment and research during the mid-1980s $[1 ; 2]$. Humans take into account reliefs when choosing their habitat. Eco-geomorphological analysis has been conducted in the last decades, and the present study aimed to determine if a person's place of residence is comfortable for the person or not. Relief is one of the main factors of any chemical, physical, or biological process in the environment. Suitability assessment of human habitat and land has been changing gradually and methodological

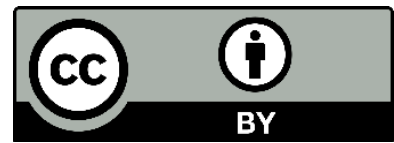

The Author(s). 2020 Open access This article is distributed under the terms of the Creative Commons Attribution 4.0 International License (https://creativecommons.org/licenses/by/4.0/), which permits unrestricted use, distribution, and reproduction in any medium, provided you give appropriate credit to the original author(s) and the source, provide a link to the Creative Commons license, and indicate if changes were made. 
approaches to modern research on ecogeomorphological assessment of landscape have aimed to develop indicators of suitable conditions for relief and to regulate the relationship between the surfaces, the population and the economy [1]. Besides, relief is the most important component of geographical coverage, and is also characteristic of other natural factors and its interactions depend greatly on the surface features. Relief is a key natural element that regulates the moisture and heat distribution on Earth, and its shape and size are closely related to the geological structure of the territory. Also, relief is a key factor (most important resource) in determining the distribution of natural resources, such as macro-microclimate, surface water, groundwater, soil, flora, and fauna [3; 4].

\section{MATERIALS AND METHODS}

A. Study area: The area studied in this research work covered the entirety of Mongolia with a total territory of nearly 1564.1 thousand square kilometers [5] and the study area covered the high Altai Mountain ranges with perpetual snow to dry-hot Gobi desert zone, also the country's climate conditions vary between extreme continental and temperate zone with monsoon wind.

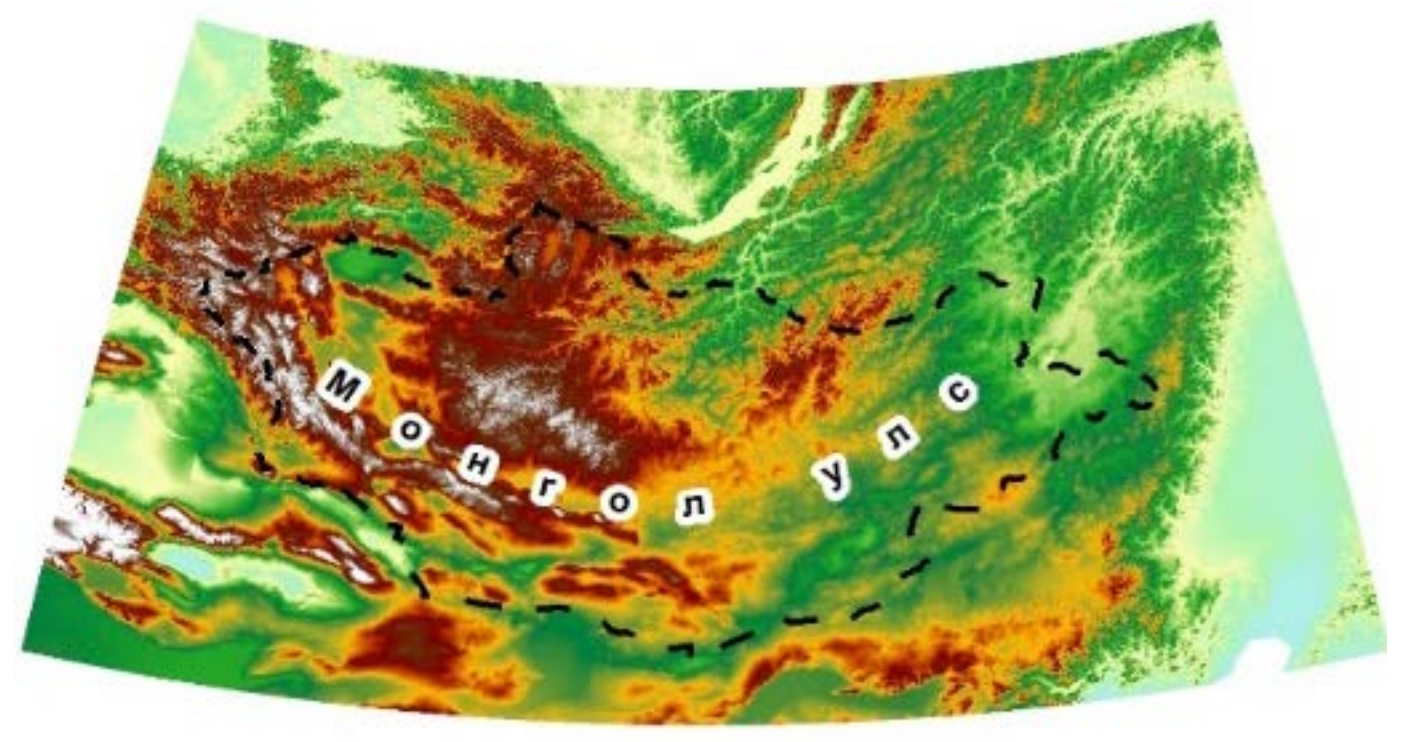

Figure 1. Study area

B. Data and materials used: Raster and vector data were used to assess the ecogeomorphological potential of Mongolia. The basic morphometric parameters of the geomorphology (elevation, slope, aspect, depth of surface dissection, distribution of the solar radiation) originating from the Shuttle Radar Topography Mission - Digital Elevation Model (SRTM DEM) [6] were retrieved. When evaluating some terrain parameters, such as the density of surface dissection, which is difficult to retrieve, more accurate Multi Error Removed Improved Terrain - Digital Elevation Model (MERIT DEM) [7] was used. MERIT DEM has made significant improvements to flat areas (relatively flat plains, rivers, and valleys) that have experienced high levels of error beyond topographic fluctuations, making it easier to estimate geomorphological elements, such as river networks, steppes, and relatively low hills.

Thematic layers were developed for the evaluation of eco-geomorphological potential using climatic data that primarily affect morphometric measurements and hydrological, geological, and geomorphological factors, and for their processes. 


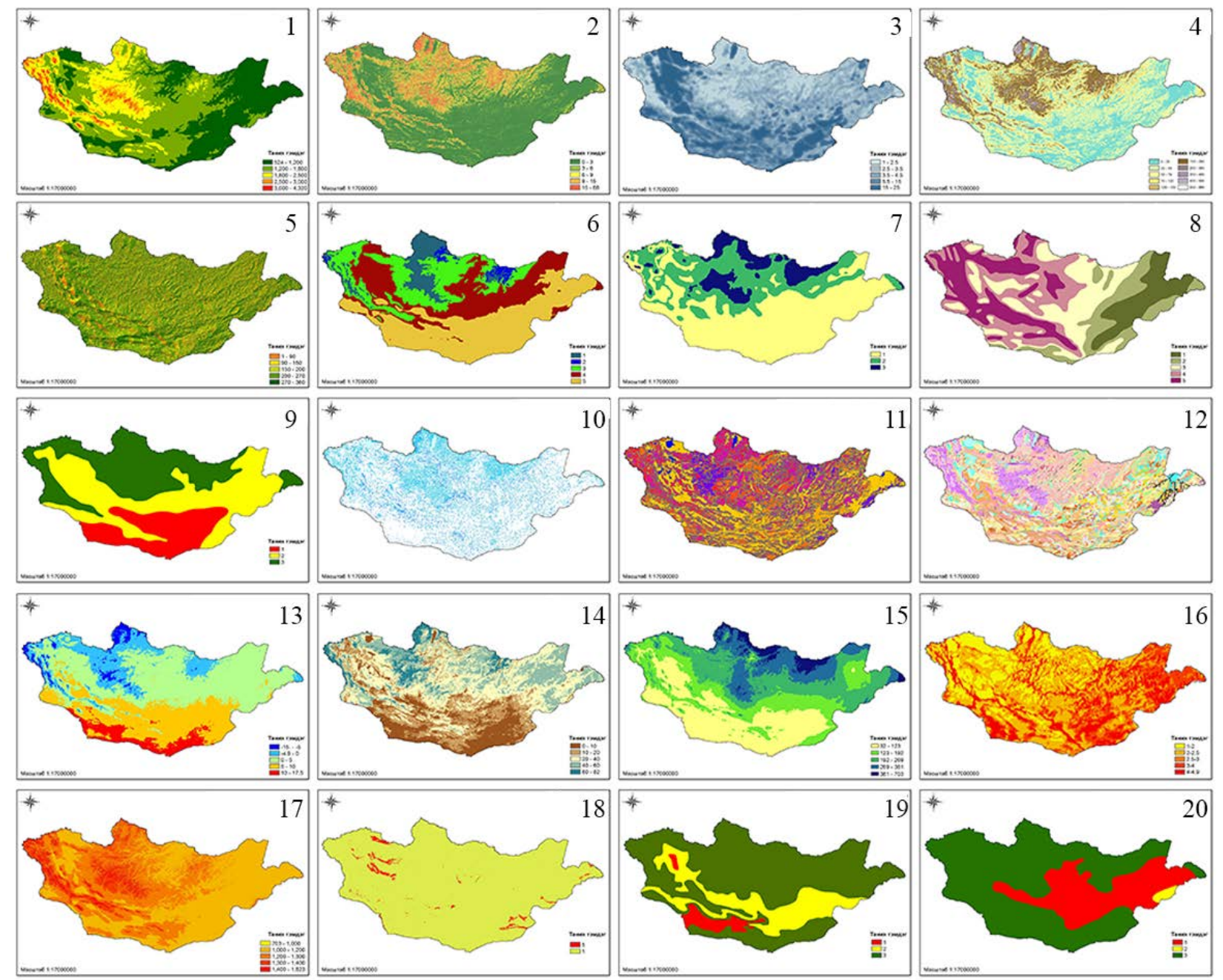

Figure 2. Key factors for evaluation of eco-geomorphological potential (1. Elevation, 2. Slope, 3. Density of surface dissection, 4. Depth of surface dissection, 5. Aspect, 6. Permafrost, 7. Density of river network, 8. Earthquake, 9. Number of windy days, 10. Hydrology, 11. Sediment, 12. Morphogenetic process, 13. Surface temperature, 14. Snow cover, 15. Total rainfall, 16. Wind power, 17. Total solar radiation /irradiance/, 18. Moving /unfixed/sand, 19. Dust storm, 20. Snowstorm)

C. Methods: Methods of quantitative analysis (mathematical, modeling, and scoring) have been used for the evaluation of the ecogeomorphological study. Scoring is an important indicator of how ecogeomorphological studies combine natural conditions and resources in an area [8]. Ecogeomorphological research is aimed at assessing the geomorphological conditions of the area for any business activity. In other words, this kind of research is important in solving problems, such as choosing the suitable form and condition of relief for optimal planning of population, livestock and agricultural location, protecting the particular object from exogenetic processes that change the relief, and anticipating the difficulties caused by relief condition. Ecogeomorphological research is a descriptive study, especially when new cities, settlements, roads, electrical and engineering networks are built, ensuring their normal operation and determining whether the engineering geomorphological condition can, in turn, affect the ability to run a business in the area and to live comfortably in the future or not. First of all, criteria need to be defined to conduct an ecogeomorphological assessment. In order to choose this criterion, it is necessary to inform the differences between engineering geomorphology and eco-geomorphology (Table 1) [3] 
Table 1. Principles of evaluating eco-geomorphology and engineering geomorphology.

Source (Evseeva N.S., 2013)

\begin{tabular}{|c|c|c|}
\hline \multirow{3}{*}{ Criteria } & \multicolumn{2}{|c|}{ Territorial assessment } \\
\hline & Engineer & Ecology \\
\hline & \multicolumn{2}{|c|}{ Geomorphological } \\
\hline Types of relief & $\begin{array}{l}\text { Assess the stability level of the surface: } \\
\text { Evaluation of endogenous and exogenous } \\
\text { processes }\end{array}$ & $\begin{array}{l}\text { Assess the surface and landscape } \\
\text { features from a safety perspective }\end{array}$ \\
\hline Paleo relief & $\begin{array}{l}\text { Assess the hydrogeological condition and } \\
\text { the impact of paleo relief: activity of karst, } \\
\text { earthquake, etc. }\end{array}$ & Assess the safety \\
\hline
\end{tabular}

Surface dissection

* Density of relief dissection

* Depth of relief dissection

Evaluate the potential level of Assess the impact of these construction: assess the extent of risk of processes on habitat and public landslides, erosion processes, floods, etc. health

Slope

Estimate the risks that may arise during architectural planning, road, and pipeline connection work

Estimate the risk of being polluted by surface water, and possible risks in communication

The objective of this research was to determine the eco-geomorphological potential of the surface components of the area. Engineering geomorphological assessment takes into account the engineering characteristics of the surface (mainly to determine the stability of the relief), while ecogeomorphological assessment aims to take into account the following characteristics and features of the surface in order to create comfortable living conditions: the consequences of people's living conditions, health, and safety (and psychological wellbeing). This assessment considers the appearance of the surface, differences, and unique formations $[3 ; 4 ; 8]$. The general scheme of the methodology for this study is shown in Figure 3.

In order to calculate the overall assessment of eco-geomorphological potential, firstly, the eco-geomorphological assessments for the population, livestock and agriculture were evaluated on a scale of 1-5 points for the values of the spatial distribution of the selected factors. When many factors are compared, one is more important than the other and is likely to have a higher importance. Therefore, the AHP (analytical hierarchy process) method was used to rank the evaluation criteria [9]. 


$$
\begin{aligned}
& \boldsymbol{B}=e+s+a+h+v+g+f+r+w+s a+g m+g e+t+s n+s r+p s+w+w s+s s+s d \\
& \boldsymbol{C}=e+s+a+h+v+g+f+r+w+s a+t+s n+s r+p s+w+w s+s s+s d \\
& \boldsymbol{C}=\text { horse }+ \text { cattle }+ \text { camel }+ \text { sheep }+ \text { goat } \\
& \boldsymbol{D}=e+s+a+h+v+f+r+w+s a+t+s n+s r+p s+w+w s \\
& \boldsymbol{A}=\mathbf{B} * 0.5+\mathbf{C} * 0.35+\mathbf{D} * 0.15
\end{aligned}
$$

** The selected indicators were ranked according to population, livestock, and agriculture and multiplied by different weighted values for each assessment. *** The eco-geomorphological assessment for livestock was evaluated for each of the 5 head of livestock and the results were summarized. **** see other letter notation in (Figure 3).

Figure 3. Method of assessing eco-geomorphological potential

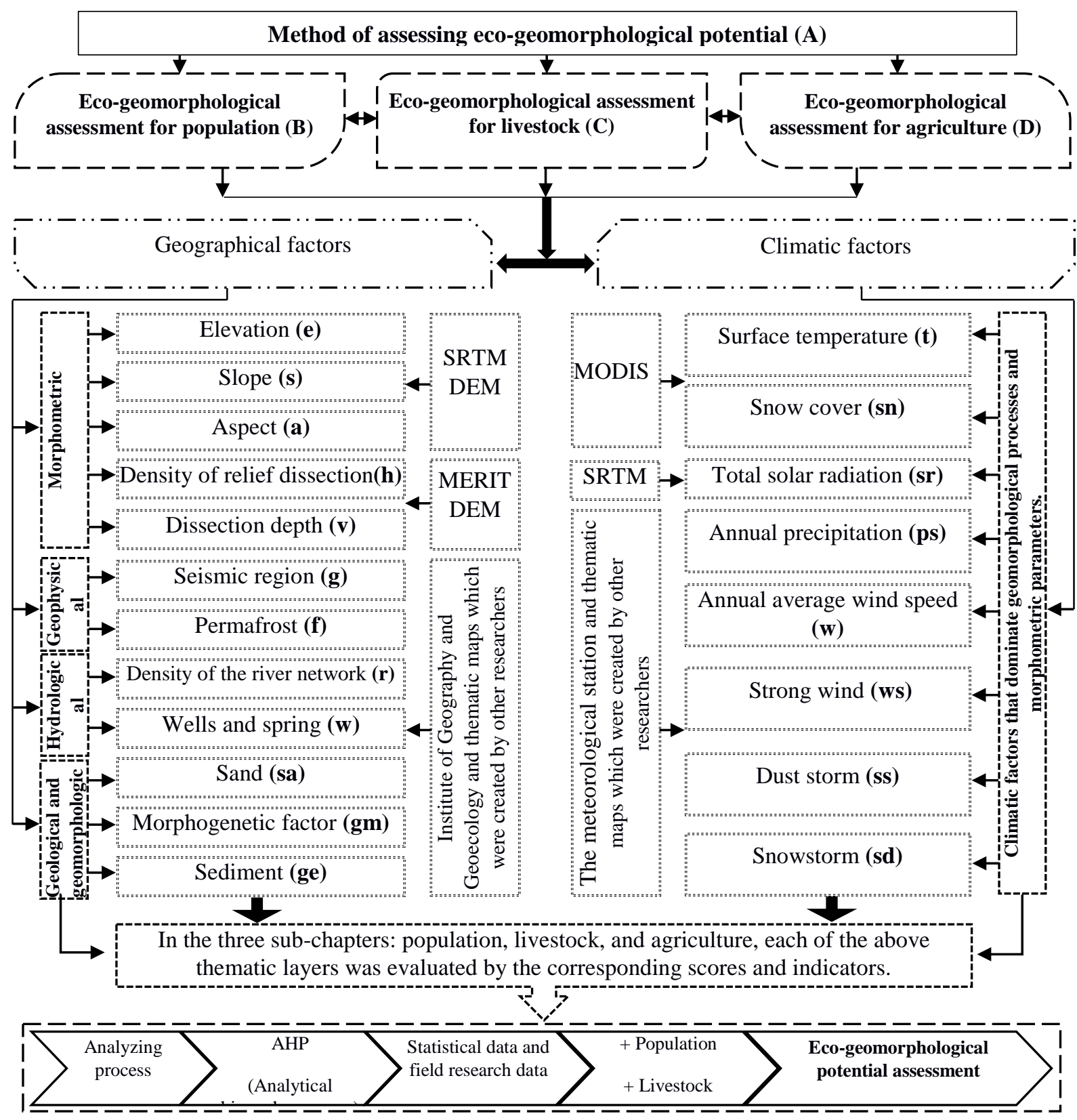




\section{RESULTS AND DISCUSSION}

Assessment of eco-geomorphological potential for the population. There is no detailed study in our country determining the surface of a comfortable living environment and construction work. In order to consider relief in a building, it is first necessary to determine the dynamic changes in the surface and the morphometric parameters [10]. In order to detect the favorable and negative conditions of geomorphological conditions in human habitat, the methodology of ecological and geomorphological assessment of the urban population was first evaluated based on the studies of [11-13]. Another important indicator in urban and residential environment is the issue of engineering infrastructures, such as roads and networks. In order to assess the ecological and geomorphological capacity of the population, it is necessary to conduct geomorphological surveys by road and infrastructure engineers.

Table 2. Eco-geomorphological potential for the population

\begin{tabular}{clcc}
\hline \multirow{2}{*}{ Eco-geomorphological potential for population } & \multicolumn{2}{c}{ Area } \\
\cline { 2 - 4 } & & sq.km & $\%$ \\
\hline 1 & (Very low) & 69723.24 & 4.5 \\
2 & (Low) & 92880.79 & 5.9 \\
3 & (Moderate) & 760858.3 & 48.6 \\
4 & (High) & 374424.4 & 23.9 \\
5 & (Very high) & 266229.3 & 17.0
\end{tabular}

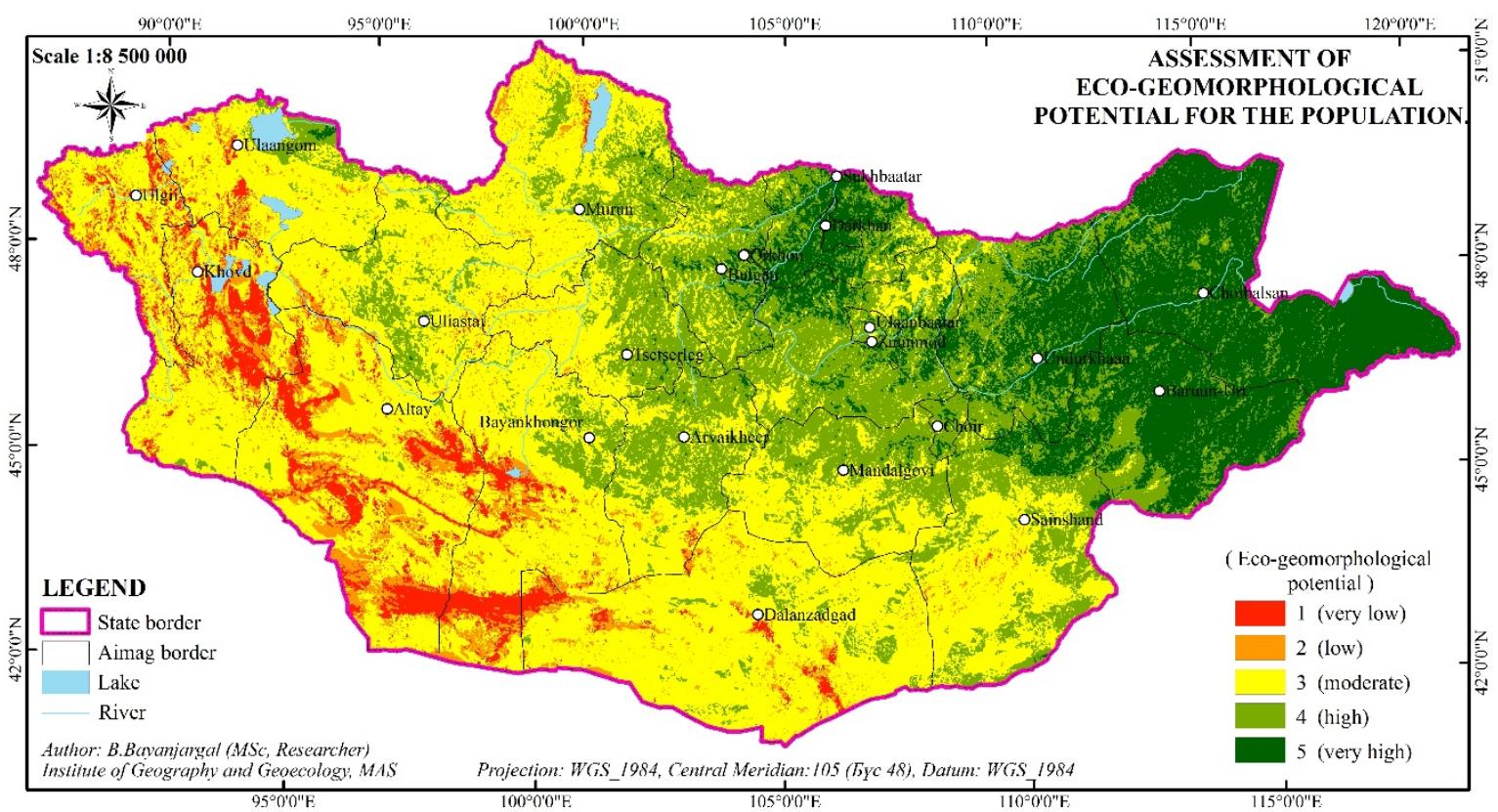

Figure 4. Assessment of eco-geomorphological potential for the population 
Table 3. Eco-geomorphological potential for the population, (by natural belts and zones)

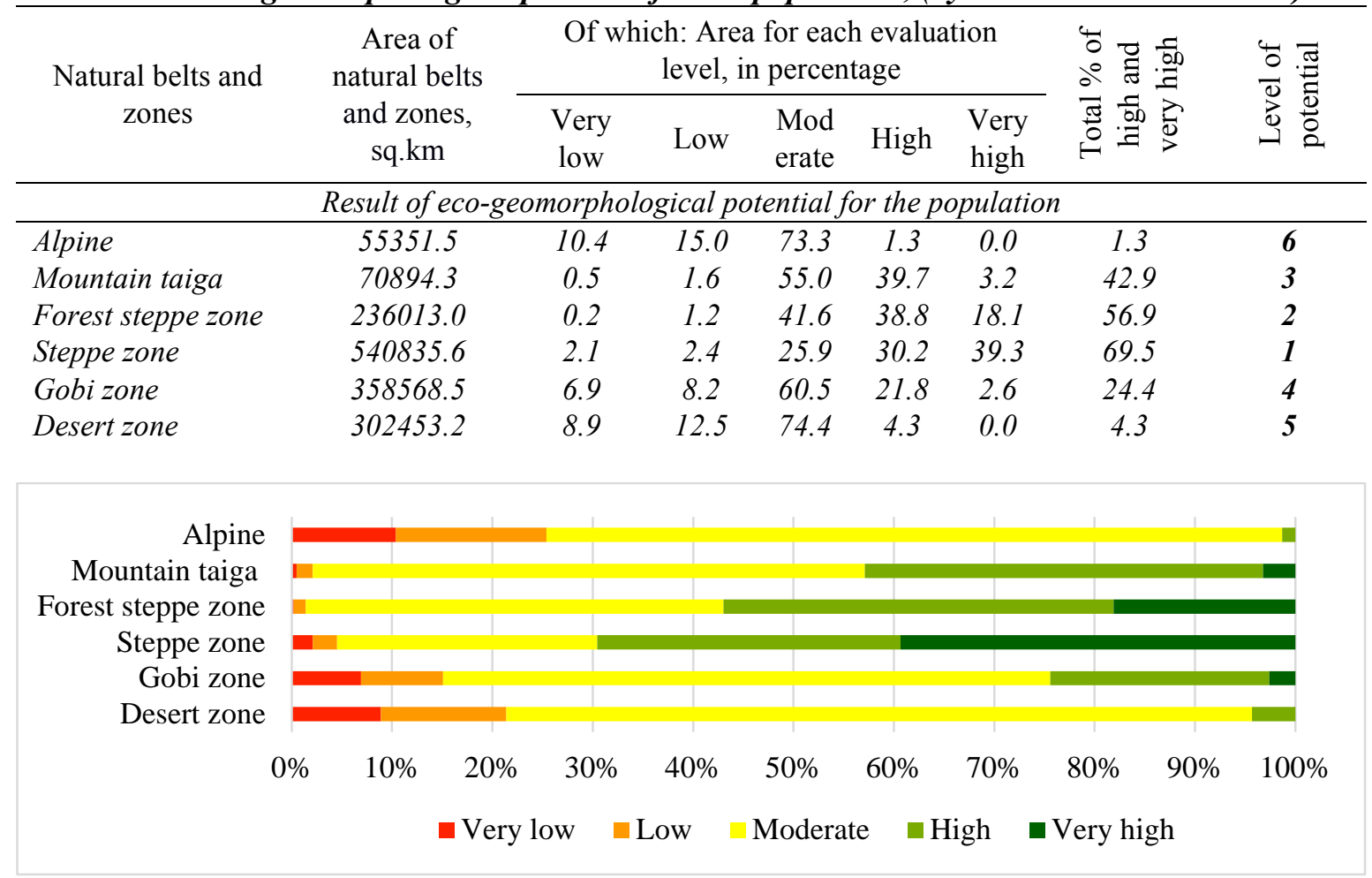

Figure 5. Eco-geomorphological potential for population (by natural belts and zones)

Comparing the assessment of ecogeomorphological potential for population by provinces and provincial municipalities: According to the statistical information of the National Statistical Office of Mongolia, the urban population category includes $2,197,970$ people, which is roughly equivalent to 70 per cent of the total population of the country. The term urban population refers to all the population and households living in the capital city, provincial centers, and villages [14-15]. This category does not include the population of rural settlements or soum centers. According to this indicator, there are about 300,000 people are living in 315 soum centers, and in total, 77 per cent of Mongolia's population, or 2.5 million people, live in province and soum centers, cities, and villages.

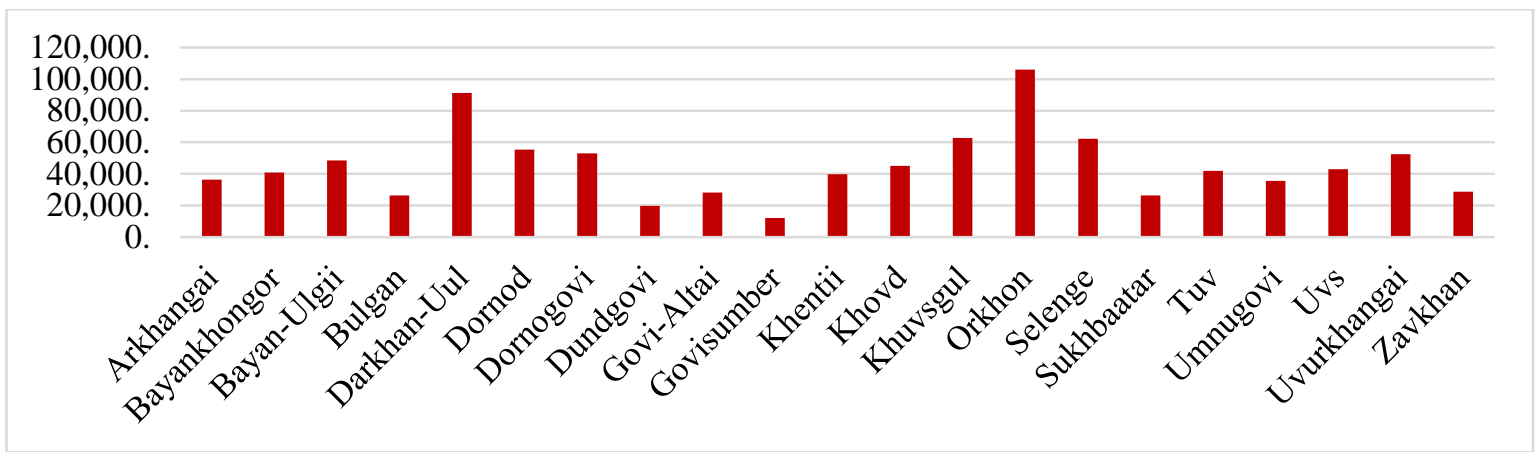

Figure 6. Number of residents in the settled areas, by aimags (provinces)

After Ulaanbaatar, Orkhon, DarkhanUul, Selenge, Khuvsgul, and Dornod aimags lead in the number of residents of settled area and Orkhon, Darkhan-Uul, Tuv, Selenge, and Bulgan aimags lead in terms of the number of migrants from 1983 to 2018.
Such inland migration, on the one hand, has been due primarily to the attractivness of the market and, secondly, temporary migration to areas with high ecological potential or favorable habitats. On the other hand, the number of migrants in the western regions such 
as Bayan-Ulgii, Zavkhan, Uvs, and Khovd aimags has been relatively high during these years. According to Sh. Oniki and B.Batbuyan's herder migration survey carried out in Bulgan aimag, 84 of the 124 households were herder households from Uvs aimag, and 95 per cent of all herders from Uvs aimag had settled in the forest-steppe and steppe zones of Selenge, Darkhan-Uul, Tuv and Bulgan aimags in the central region [16] of the country.

Table 4. Eco-geomorphological potential for the population (by aimags)

\begin{tabular}{|c|c|c|c|c|c|c|c|c|}
\hline \multirow{2}{*}{$\begin{array}{c}\text { Aimags } \\
\text { (Provinces), and } \\
\text { Capital city }\end{array}$} & \multirow{2}{*}{$\begin{array}{c}\text { Area of aimags and } \\
\text { capital city } \\
\text { sq.km }\end{array}$} & \multicolumn{5}{|c|}{$\begin{array}{l}\text { Of which: Area for each evaluation level, in } \\
\text { percent }\end{array}$} & \multirow{2}{*}{ 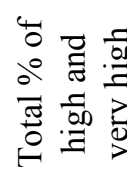 } & \multirow{2}{*}{ 虫 } \\
\hline & & Very low & Low & Moderate & High & $\begin{array}{l}\text { Very } \\
\text { high }\end{array}$ & & \\
\hline \multicolumn{9}{|c|}{ Result of eco-geomorphological potential for population } \\
\hline Arkhangai & 55313.8 & 0.3 & 1.6 & 54.4 & 42.7 & 1.1 & 43.7 & 13 \\
\hline Bayankhongor & 115977.8 & 9.9 & 12.7 & 67.7 & 9.6 & 0.0 & 9.6 & 18 \\
\hline Bayan-Ulgii & 45704.9 & 15.6 & 17.7 & 66.0 & 0.8 & 0.0 & 0.8 & 21 \\
\hline Bulgan & 48733.0 & 0.0 & 0.1 & 22.8 & 67.4 & 9.7 & 77.1 & 10 \\
\hline Darkhan-Uul & 3275.0 & 0.0 & 0.0 & 0.1 & 13.4 & 86.5 & 99.9 & 1 \\
\hline Dornod & 123597.4 & 0.0 & 0.0 & 0.1 & 11.3 & 88.5 & 99.9 & 2 \\
\hline Dornogovi & 109472.3 & 0.3 & 1.3 & 55.3 & 35.6 & 7.5 & 43.1 & 14 \\
\hline Dundgovi & 74690.3 & 0.0 & 0.5 & 54.2 & 44.3 & 1.0 & 45.3 & 12 \\
\hline Govi-Altai & 141447.7 & 17.8 & 21.1 & 60.4 & 0.7 & 0.0 & 0.7 & 22 \\
\hline Govisumber & 5541.8 & 0.0 & 0.0 & 5.1 & 79.6 & 15.3 & 94.9 & 6 \\
\hline Khentii & 80325.1 & 0.0 & 0.0 & 5.0 & 42.3 & 52.6 & 95.0 & 5 \\
\hline Khovd & 76060.4 & 18.3 & 17.6 & 62.8 & 1.2 & 0.0 & 1.2 & 20 \\
\hline Khuvsgul & 100628.8 & 0.8 & 3.5 & 70.7 & 24.4 & 0.6 & 25.0 & 15 \\
\hline Orkhon & 844.0 & 0.0 & 0.0 & 1.2 & 48.8 & 50.1 & 98.8 & 4 \\
\hline Selenge & 41152.6 & 0.0 & 0.0 & 8.9 & 42.7 & 48.4 & 91.1 & 7 \\
\hline Sukhbaatar & 82287.2 & 0.0 & 0.0 & 0.9 & 25.8 & 73.3 & 99.1 & 3 \\
\hline$T u v$ & 74042.4 & 0.0 & 0.1 & 17.4 & 64.7 & 17.8 & 82.6 & 9 \\
\hline Ulaanbaatar & 4704.4 & 0.0 & 0.0 & 13.3 & 74.7 & 12.0 & 86.7 & 8 \\
\hline Umnugovi & 165380.5 & 3.7 & 6.7 & 83.7 & 6.0 & 0.0 & 6.0 & 19 \\
\hline Uvs & 69585.4 & 4.1 & 6.7 & 76.0 & 12.3 & 0.8 & 13.2 & 17 \\
\hline Uvurkhangai & 62895.3 & 0.6 & 1.9 & 46.7 & 50.0 & 0.8 & 50.8 & 11 \\
\hline Zavkhan & 82455.7 & 1.0 & 3.8 & 76.2 & 19.0 & 0.0 & 19.0 & 16 \\
\hline
\end{tabular}

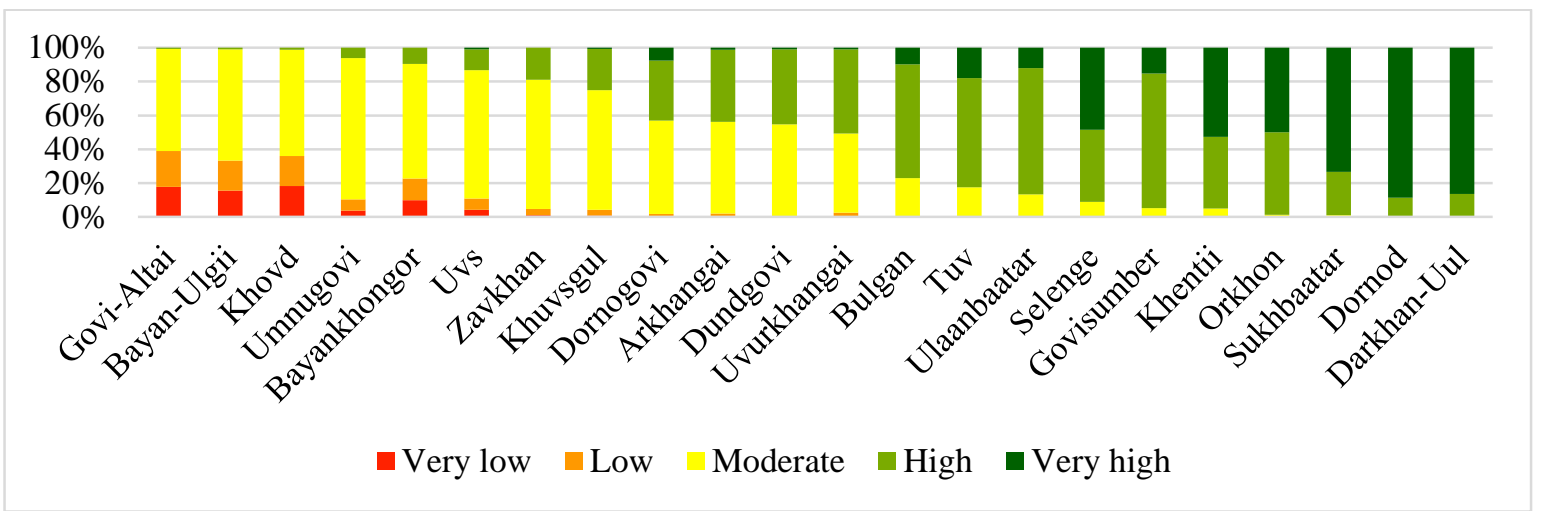

Figure 7. Eco-geomorphological potential for population (by aimags)

Assessment of eco-geomorphological potential for livestock: Eco-geomorphological potential and evaluation criteria were set differently for each of the types of livestock in the spatial distribution map of landscape, and the results were summarized. In this study, we estimated that 3.8 per cent of the area had low (2) potential, 64.6 per cent had moderate (3) potential, and 31.6 per cent had high (4) potential, while there were no areas with very low (1) and very high (5) potentials since the location of the type of livestock and the 
ecological favorable areas did not condition each other's location. This means that it is not possible to raise five heads of livestock in one unit of land, one household, and on only one pasture land. On the one hand, assessment of the eco-geomorphological potential for livestock has the advantage of complementing assessment of the eco-geomorphological potential for the population because more than 20 per cent of our population are engaged in nomadic livestock breeding. Evaluation criteria were calculated based on studies by [12,17-19].

Table 5. Eco-geomorphological potential for livestock

\begin{tabular}{clcc}
\hline \multirow{2}{*}{ Eco-geomorphological potential for livestock } & \multicolumn{2}{c}{ Area } \\
\cline { 3 - 4 } & & sq. km & $\%$ \\
\hline 2 & (Low) & 59453.18 & 3.8 \\
4 & (Moderate) & 1009867 & 64.6 \\
4 & (High) & 494795.9 & 31.6
\end{tabular}

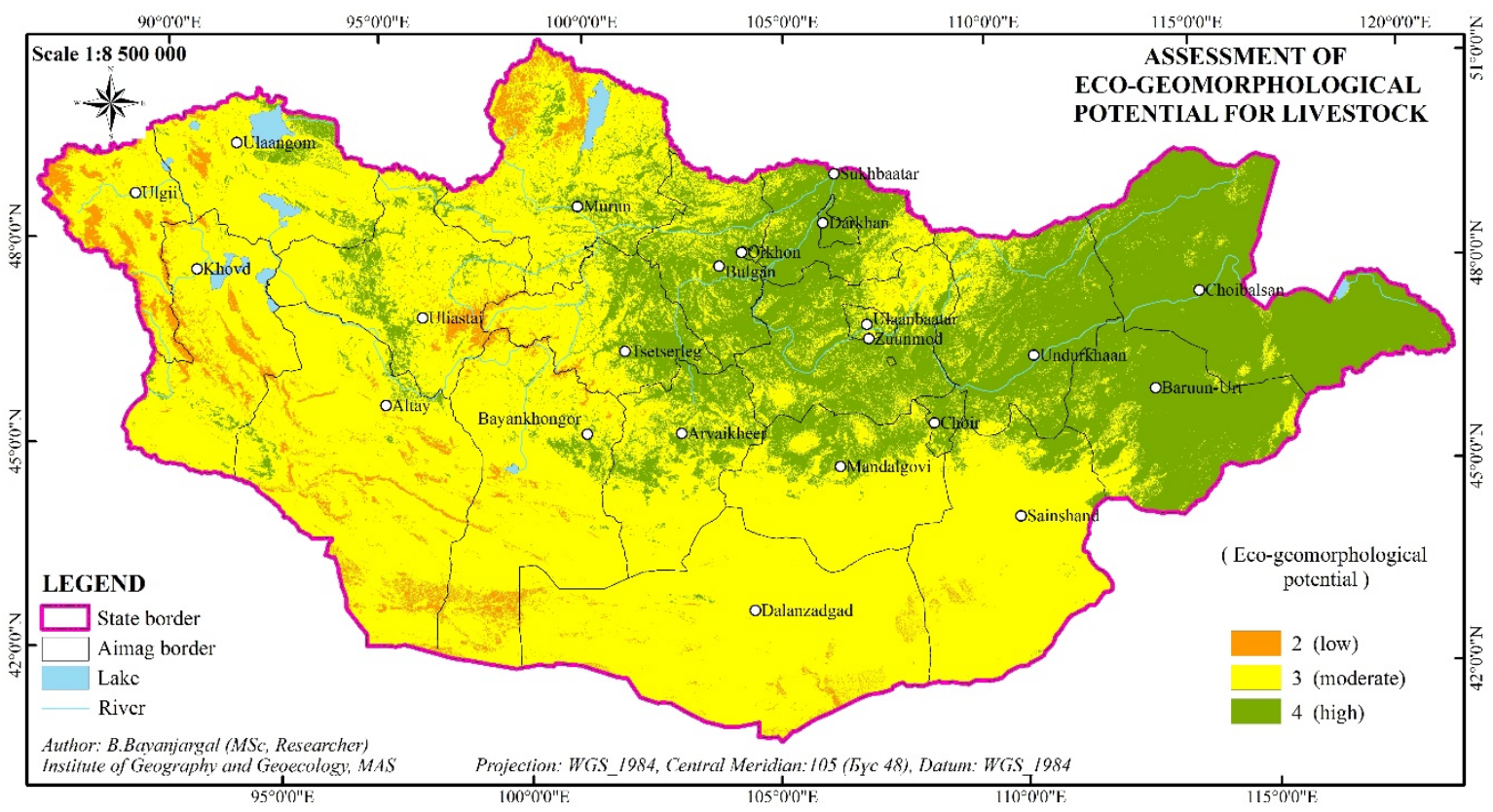

Figure 8. Assessment of eco-geomorphological potential for livestock

Table 6. Eco-geomorphological potential for livestock, (by natural belts and zones)

\begin{tabular}{|c|c|c|c|c|c|c|c|c|}
\hline \multirow{2}{*}{$\begin{array}{c}\text { Natural belts and } \\
\text { zones }\end{array}$} & \multirow{2}{*}{$\begin{array}{c}\text { Area of natural } \\
\text { belts and zones, } \\
\text { sq. } \mathrm{km}\end{array}$} & \multicolumn{5}{|c|}{$\begin{array}{c}\text { Of which: Area for each evaluation } \\
\text { level, in percent }\end{array}$} & \multirow{2}{*}{ 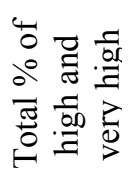 } & \multirow{2}{*}{ 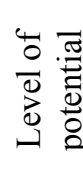 } \\
\hline & & $\begin{array}{l}\text { Very } \\
\text { low }\end{array}$ & Low & $\begin{array}{l}\text { Mod } \\
\text { erate }\end{array}$ & High & $\begin{array}{l}\text { Very } \\
\text { high }\end{array}$ & & \\
\hline \multicolumn{9}{|c|}{ Result of eco-geomorphological potential for the livestock } \\
\hline Alpine & 55351.5 & 0 & 45.8 & 54.1 & 0.1 & 0 & 0.1 & 6 \\
\hline Mountain taiga & 70894.3 & 0 & 4.0 & 78.3 & 17.7 & 0 & 17.7 & 3 \\
\hline Forest steppe zone & 236013.0 & 0 & 0.8 & 52.4 & 46.8 & 0 & 46.8 & 2 \\
\hline Steppe zone & 540835.6 & 0 & 1.7 & 35.4 & 62.8 & 0 & 62.8 & 1 \\
\hline Gobi zone & 358568.5 & 0 & 1.2 & 89.8 & 8.9 & 0 & 8.9 & 4 \\
\hline Desert zone & 302453.2 & 0 & 5.1 & 94.5 & 0.4 & 0 & 0.4 & 5 \\
\hline
\end{tabular}




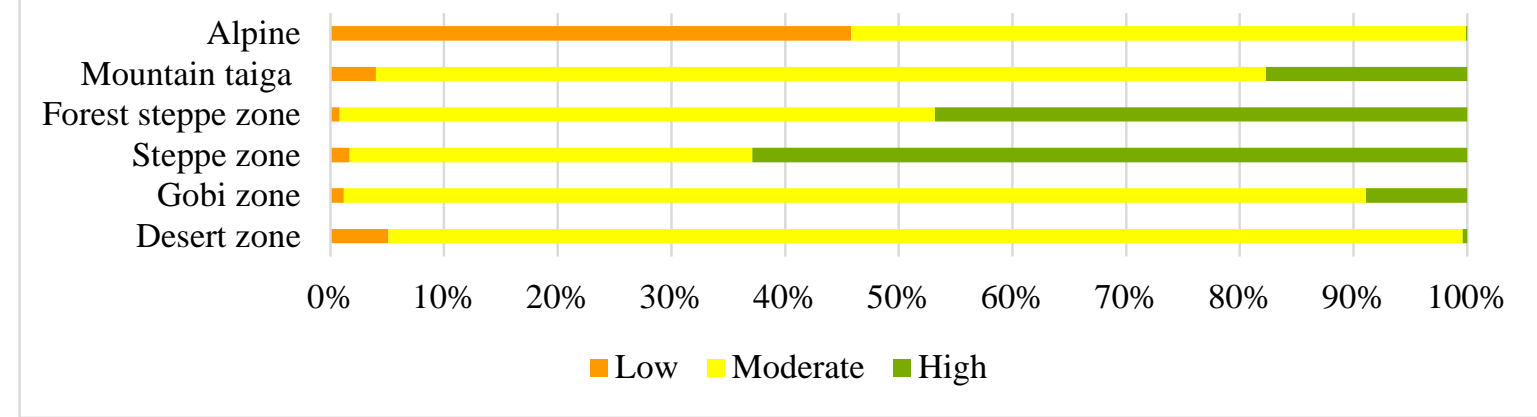

Figure 9. Eco-geomorphological potential for livestock, (by natural belts and zones)

Table 7. Eco-geomorphological potential for livestock, (by aimags)

\begin{tabular}{|c|c|c|c|c|c|c|c|c|}
\hline \multirow{2}{*}{$\begin{array}{c}\text { Aimags } \\
\text { (Provinces), } \\
\text { and Capital } \\
\text { city }\end{array}$} & \multirow{2}{*}{$\begin{array}{c}\text { Area of } \\
\text { aimags and } \\
\text { capital city } \\
\text { sq.km }\end{array}$} & \multicolumn{5}{|c|}{$\begin{array}{l}\text { Of which: Area for each evaluation } \\
\text { level, in percent }\end{array}$} & \multirow{2}{*}{ 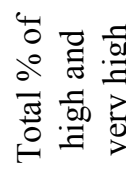 } & \multirow{2}{*}{ 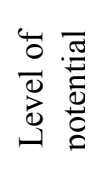 } \\
\hline & & $\begin{array}{l}\text { Very } \\
\text { low }\end{array}$ & Low & $\begin{array}{l}\text { Mod } \\
\text { erate }\end{array}$ & High & $\begin{array}{l}\text { Very } \\
\text { high }\end{array}$ & & \\
\hline \multicolumn{9}{|c|}{ Result of eco-geomorphological potential for livestock } \\
\hline Arkhangai & 55313.8 & 0.0 & 3.4 & 57.6 & 39.1 & 0.0 & 39.1 & 11 \\
\hline Bayankhongor & 115977.8 & 0.0 & 6.4 & 89.7 & 3.9 & 0.0 & 3.9 & 18 \\
\hline Bayan-Ulgii & 45704.9 & 0.0 & 27.6 & 72.1 & 0.3 & 0.0 & 0.3 & 21 \\
\hline Bulgan & 48733.0 & 0.0 & 0.0 & 32.3 & 67.7 & 0.0 & 67.7 & 8 \\
\hline Darkhan-Uul & 3275.0 & 0.0 & 0.0 & 4.3 & 95.7 & 0.0 & 95.7 & 2 \\
\hline Dornod & 123597.4 & 0.0 & 0.0 & 2.8 & 97.2 & 0.0 & 97.2 & 1 \\
\hline Dornogovi & 109472.3 & 0.0 & 0.6 & 91.5 & 7.9 & 0.0 & 7.9 & 17 \\
\hline Dundgovi & 74690.3 & 0.0 & 0.0 & 76.3 & 23.7 & 0.0 & 23.7 & 13 \\
\hline Govi-Altai & 141447.7 & 0.0 & 7.8 & 90.1 & 2.1 & 0.0 & 2.1 & 19 \\
\hline Govisumber & 5541.8 & 0.0 & 0.0 & 21.0 & 79.0 & 0.0 & 79.0 & 6 \\
\hline Khentii & 80325.1 & 0.0 & 0.0 & 19.3 & 80.7 & 0.0 & 80.7 & 5 \\
\hline Khovd & 76060.4 & 0.0 & 9.1 & 89.1 & 1.7 & 0.0 & 1.7 & 20 \\
\hline Khuvsgul & 100628.8 & 0.0 & 8.8 & 75.3 & 15.8 & 0.0 & 15.8 & 14 \\
\hline Orkhon & 844.0 & 0.0 & 0.0 & 14.2 & 85.8 & 0.0 & 85.8 & 4 \\
\hline Selenge & 41152.6 & 0.0 & 0.0 & 24.1 & 75.9 & 0.0 & 75.9 & 7 \\
\hline Sukhbaatar & 82287.2 & 0.0 & 0.0 & 11.9 & 88.1 & 0.0 & 88.1 & 3 \\
\hline Tuv & 74042.4 & 0.0 & 0.1 & 32.8 & 67.1 & 0.0 & 67.1 & 9 \\
\hline Ulaanbaatar & 4704.4 & 0.0 & 0.0 & 42.1 & 57.9 & 0.0 & 57.9 & 10 \\
\hline Umnugovi & 165380.5 & 0.0 & 2.3 & 97.5 & 0.1 & 0.0 & 0.1 & 22 \\
\hline$U v s$ & 69585.4 & 0.0 & 2.6 & 86.2 & 11.2 & 0.0 & 11.2 & 16 \\
\hline Uvurkhangai & 62895.3 & 0.0 & 0.2 & 67.5 & 32.3 & 0.0 & 32.3 & 12 \\
\hline Zavkhan & 82455.7 & 0.0 & 4.7 & 81.5 & 13.8 & 0.0 & 13.8 & 15 \\
\hline
\end{tabular}

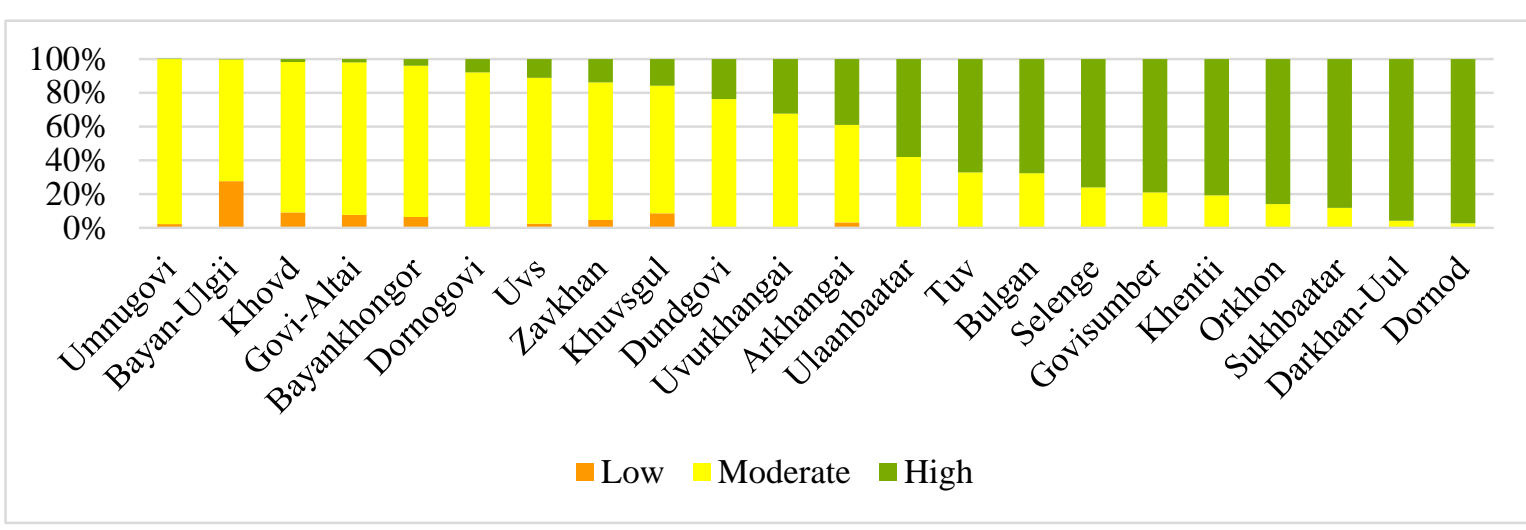

Figure 10. Eco-geomorphological potential for livestock, (by aimags) 
Assessment of eco-geomorphological potential for agriculture: The rugged nature of Mongolia's mountains and depressions has a different effect on agriculture. The impact of relief on agriculture should be considered primarily in relation to surface slope, surface obstacle, mountain slopes, absolute altitude, and micro-features of relief. Relief has a significant effect on the natural resources indispensable for agriculture, such as precipitation, solar radiation, fertile soils, and surface and groundwater distribution. For example, there are thick forests and foliage at the back side of a mountain, but there are no forests in the front part. This is directly related to the micro-differences in the relief. Therefore, the yield per hectare of two farms in the same geographical area appears to be different. The evaluation criteria of Munkhdulam (2017) were followed since it was difficult to develop criteria for this sub-topic [20].

Table 8. Eco-geomorphological potential for agriculture

\begin{tabular}{clcc}
\hline \multirow{2}{*}{ Eco-geomorphological potential for agriculture } & \multicolumn{2}{c}{ Area } \\
\cline { 3 - 4 } & & sq. $\mathrm{km}$ & $\%$ \\
\hline 1 & (Very low) & 11106.11 & 0.7 \\
3 & (Low) & 112862.2 & 7.2 \\
4 & (Hoderate) & 609494 & 39.0 \\
5 & (Very high) & 555316.3 & 35.5 \\
& & 275337.3 & 17.6
\end{tabular}

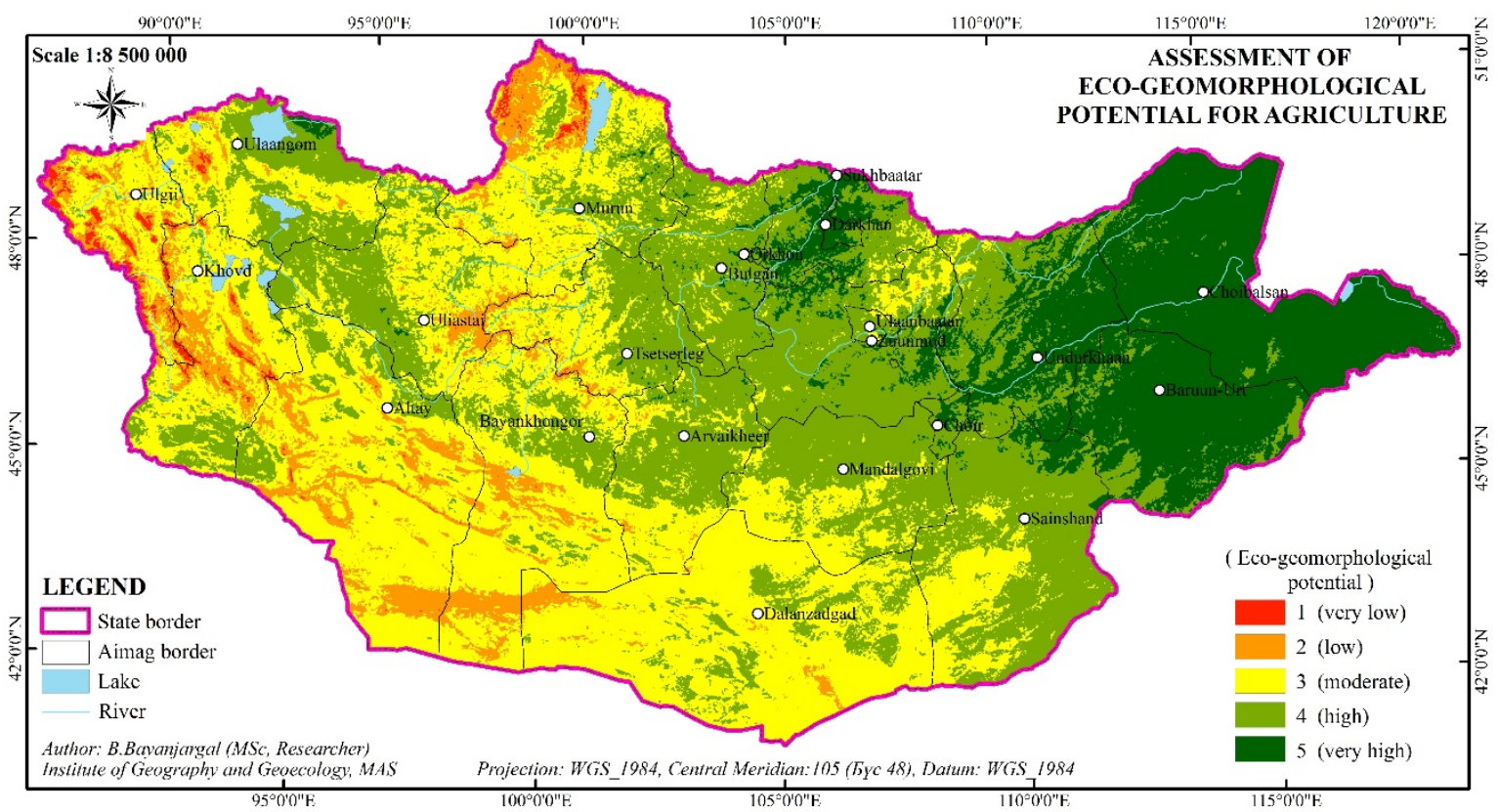

Figure 11. Assessment of eco-geomorphological potential for agriculture

Table 9. Eco-geomorphological potential for agriculture, (by natural belts and zones)

\begin{tabular}{|c|c|c|c|c|c|c|c|c|}
\hline \multirow{2}{*}{$\begin{array}{l}\text { Natural belts and } \\
\text { zones }\end{array}$} & \multirow{2}{*}{$\begin{array}{c}\text { Area of } \\
\text { natural belts } \\
\text { and zones, } \\
\text { sq.km }\end{array}$} & \multicolumn{5}{|c|}{$\begin{array}{l}\text { Of which: Area for each evaluation } \\
\text { level, in percent }\end{array}$} & \multirow{2}{*}{ 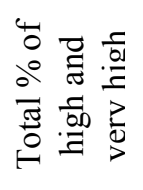 } & \multirow{2}{*}{ 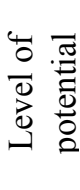 } \\
\hline & & $\begin{array}{l}\text { Very } \\
\text { low }\end{array}$ & Low & $\begin{array}{l}\text { Mod } \\
\text { erate }\end{array}$ & High & $\begin{array}{l}\text { Very } \\
\text { high }\end{array}$ & & \\
\hline \multicolumn{9}{|c|}{ Result of eco-geomorphological potential for the agriculture } \\
\hline Alpine & 55351.5 & 7.6 & 40.1 & 51.5 & 0.8 & 0.0 & 0.8 & 6 \\
\hline Mountain taiga & 70894.3 & 0.2 & 3.4 & 54.7 & 39.6 & 2.1 & 41.7 & 3 \\
\hline Forest steppe zone & 236013.0 & 0.0 & 2.1 & 37.1 & 47.6 & 13.2 & 60.8 & 2 \\
\hline Steppe zone & 540835.6 & 0.5 & 5.1 & 19.5 & 46.5 & 28.4 & 75.0 & 1 \\
\hline Gobi zone & 358568.5 & 0.4 & 16.1 & 43.0 & 37.8 & 2.8 & 40.6 & 4 \\
\hline Desert zone & 302453.2 & 1.2 & 22.5 & 63.6 & 12.8 & 0.0 & 12.8 & 5 \\
\hline
\end{tabular}


Alpine

Mountain taiga

Forest steppe zone

Steppe zone

Gobi zone

Desert zone

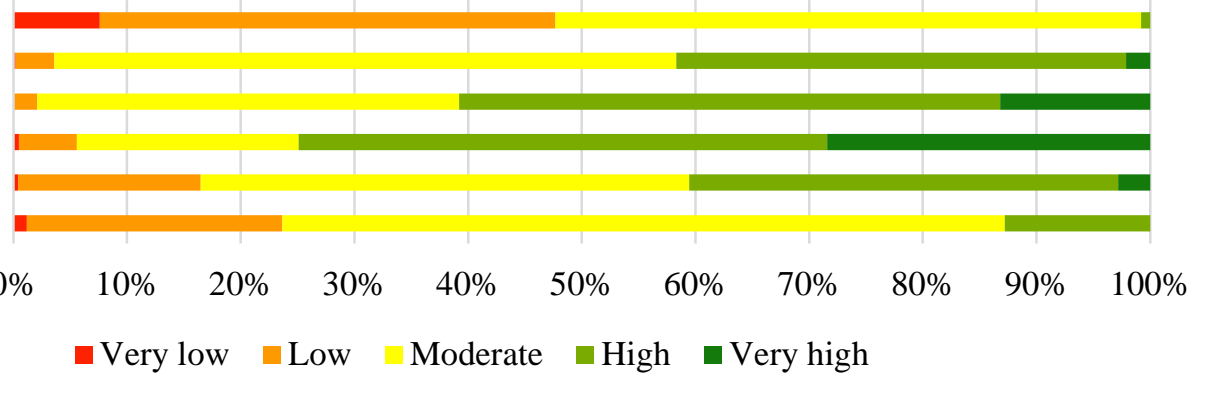

Figure 12. Eco-geomorphological potential for agriculture, (by natural belts and zones)

Table 10. Eco-geomorphological potential for agriculture, (by aimags)

\begin{tabular}{|c|c|c|c|c|c|c|c|c|}
\hline \multirow{2}{*}{$\begin{array}{c}\text { Aimags } \\
\text { (Provinces), } \\
\text { and Capital } \\
\text { city }\end{array}$} & \multirow{2}{*}{$\begin{array}{c}\text { Area of } \\
\text { aimags and } \\
\text { capital city } \\
\text { sq.km }\end{array}$} & \multicolumn{5}{|c|}{$\begin{array}{l}\text { Of which: Area for each evaluation } \\
\text { level, in percent }\end{array}$} & \multirow{2}{*}{ 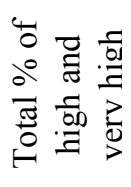 } & \multirow{2}{*}{ 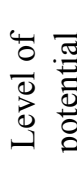 } \\
\hline & & $\begin{array}{l}\text { Very } \\
\text { low }\end{array}$ & Low & $\begin{array}{l}\text { Mod } \\
\text { erate }\end{array}$ & High & $\begin{array}{l}\text { Very } \\
\text { high }\end{array}$ & & \\
\hline \multicolumn{9}{|c|}{ Result of eco-geomorphological potential for agriculture } \\
\hline Arkhangai & 55313.8 & 0.1 & 6.2 & 40.0 & 53.2 & 0.5 & 53.7 & 14 \\
\hline Bayankhongor & 115977.8 & 0.0 & 15.7 & 65.5 & 18.8 & 0.0 & 18.8 & 19 \\
\hline Bayan-Ulgii & 45704.9 & 13.4 & 31.0 & 52.3 & 3.3 & 0.0 & 3.3 & 22 \\
\hline Bulgan & 48733.0 & 0.0 & 0.0 & 11.3 & 84.8 & 3.9 & 88.7 & 10 \\
\hline Darkhan-Uul & 3275.0 & 0.0 & 0.0 & 0.0 & 23.4 & 76.6 & 100.0 & 2 \\
\hline Dornod & 123597.4 & 0.0 & 0.0 & 0.0 & 2.9 & 97.1 & 100.0 & 4 \\
\hline Dornogovi & 109472.3 & 0.0 & 0.0 & 24.8 & 69.2 & 6.0 & 75.2 & 11 \\
\hline Dundgovi & 74690.3 & 0.0 & 0.0 & 32.9 & 67.0 & 0.1 & 67.1 & 12 \\
\hline Govi-Altai & 141447.7 & 0.3 & 19.3 & 68.3 & 12.2 & 0.0 & 12.2 & 21 \\
\hline Govisumber & 5541.8 & 0.0 & 0.0 & 0.0 & 64.9 & 35.1 & 100.0 & 5 \\
\hline Khentii & 80325.1 & 0.0 & 0.0 & 2.5 & 43.1 & 54.4 & 97.5 & 6 \\
\hline Khovd & 76060.4 & 2.2 & 20.6 & 58.2 & 19.0 & 0.0 & 19.0 & 18 \\
\hline Khuvsgul & 100628.8 & 2.2 & 17.7 & 52.2 & 27.5 & 0.4 & 27.9 & 17 \\
\hline Orkhon & 844.0 & 0.0 & 0.0 & 0.0 & 67.1 & 32.9 & 100.0 & 2 \\
\hline Selenge & 41152.6 & 0.0 & 0.0 & 6.5 & 55.8 & 37.7 & 93.5 & 7 \\
\hline Sukhbaatar & 82287.2 & 0.0 & 0.0 & 0.0 & 15.1 & 84.9 & 100.0 & 1 \\
\hline$T u v$ & 74042.4 & 0.0 & 0.1 & 9.0 & 78.4 & 12.5 & 90.9 & 8 \\
\hline Ulaanbaatar & 4704.4 & 0.0 & 0.0 & 11.3 & 79.6 & 9.1 & 88.7 & 9 \\
\hline Umnugovi & 165380.5 & 0.0 & 3.5 & 81.3 & 15.2 & 0.0 & 15.2 & 20 \\
\hline$U v s$ & 69585.4 & 0.6 & 5.0 & 40.8 & 51.1 & 2.4 & 53.5 & 15 \\
\hline Uvurkhangai & 62895.3 & 0.0 & 1.3 & 36.1 & 62.2 & 0.3 & 62.5 & 13 \\
\hline Zavkhan & 82455.7 & 0.0 & 7.0 & 48.0 & 44.6 & 0.3 & 44.9 & 16 \\
\hline
\end{tabular}

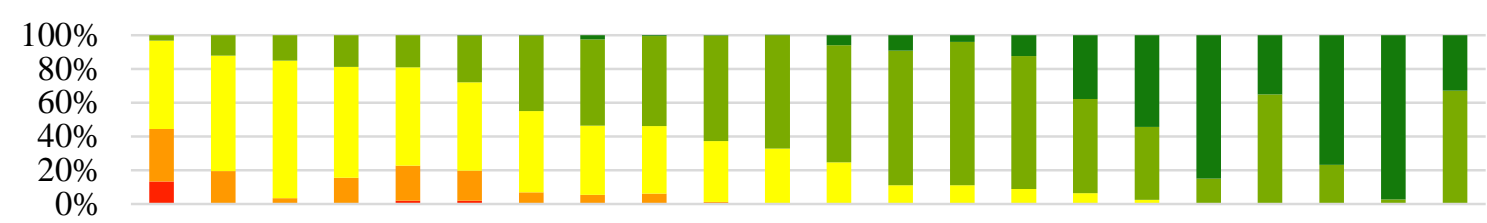

$0 \%$

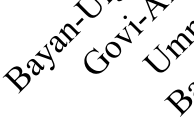

$$
\text { घery low Low Moderate } \quad \text { High } \square \text { Very high }
$$

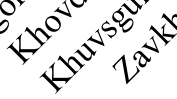

Figure 13. Eco-geomorphological potential for agriculture, (by aimags) 
As of 2019, Mongolia was cultivating a total of 507,942.9 hectares of land, of which 85 per cent is in Selenge, Tuv, Bulgan, Dornod, Khentii, and Darkhan-Uul aimags [15]. According to our research, in Dornod, Orkhon, Sukhbaatar, Darkhan-Uul, Tuv, and Selenge aimags, the potential was "very high" in terms of eco-geomorphological assessment for agriculture.
Assessment of the eco-geomorphological potential of Mongolia: The ecogeomorphological potential assessment map of Mongolia was produced using the above three thematic layers (eco-geomorphological potential assessment for population, livestock, and agriculture), which had been rated on a scale of 1-5, along with the weights calculated using the GIS-based Analytic Hierarchy Process (AHP).

Table 11. The Eco-geomorphological potential of Mongolia

\begin{tabular}{clcc}
\hline \multirow{2}{*}{ Eco-geomorphological potential of Mongolia } & \multicolumn{2}{c}{ Area } \\
\cline { 3 - 4 } & & (Very low) & 11954.5 \\
\hline 2 & (Low) & 183001.8 & 11.7 \\
3 & (Moderate) & 607763.7 & 38.9 \\
4 & (High) & 565544.2 & 36.2 \\
5 & (Very high) & 195851.8 & 12.5
\end{tabular}

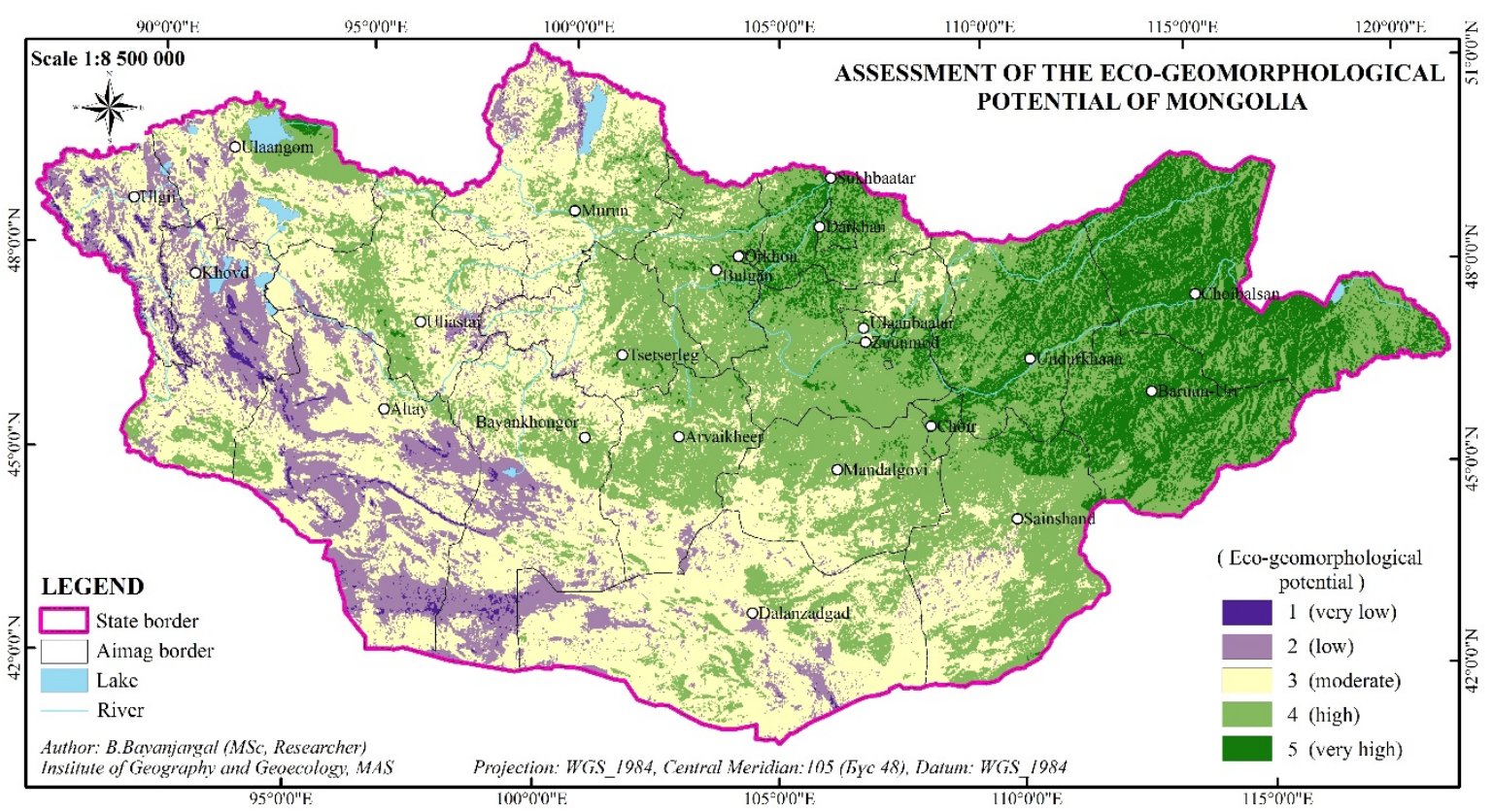

Figure 14. Assessment of the eco-geomorphological potential of Mongolia

Table 12. Assessment of the eco-geomorphological potential of Mongolia, (by natural belts and zones)

\begin{tabular}{|c|c|c|c|c|c|c|c|c|}
\hline \multirow{2}{*}{$\begin{array}{l}\text { Natural belts and } \\
\text { zones }\end{array}$} & \multirow{2}{*}{$\begin{array}{c}\text { Area of } \\
\text { natural belts } \\
\text { and zones, } \\
\text { sq.km }\end{array}$} & \multicolumn{5}{|c|}{$\begin{array}{l}\text { Of which: Area for each evaluation } \\
\text { level, in percent }\end{array}$} & \multirow{2}{*}{ 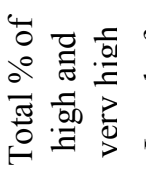 } & \multirow{2}{*}{ 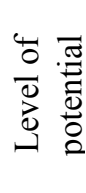 } \\
\hline & & $\begin{array}{l}\text { Very } \\
\text { low }\end{array}$ & Low & $\begin{array}{l}\text { Mod } \\
\text { erate }\end{array}$ & High & $\begin{array}{l}\text { Very } \\
\text { high }\end{array}$ & & \\
\hline \multicolumn{9}{|c|}{ Result of eco-geomorphological potential of Mongolia } \\
\hline Alpine & 55351.5 & 7.6 & 40.1 & 51.5 & 0.8 & 0.0 & 0.8 & 6 \\
\hline Mountain taiga & 70894.3 & 0.2 & 3.4 & 54.7 & 39.6 & 2.1 & 41.7 & 3 \\
\hline Forest steppe zone & 236013.0 & 0.0 & 2.1 & 37.1 & 47.6 & 13.2 & 60.8 & 2 \\
\hline Steppe zone & 540835.6 & 0.5 & 5.1 & 19.5 & 46.5 & 28.4 & 75.0 & 1 \\
\hline Gobi zone & 358568.5 & 0.4 & 16.1 & 43.0 & 37.8 & 2.8 & 40.6 & 4 \\
\hline Desert zone & 302453.2 & 1.2 & 22.5 & 63.6 & 12.8 & 0.0 & 12.8 & 5 \\
\hline
\end{tabular}




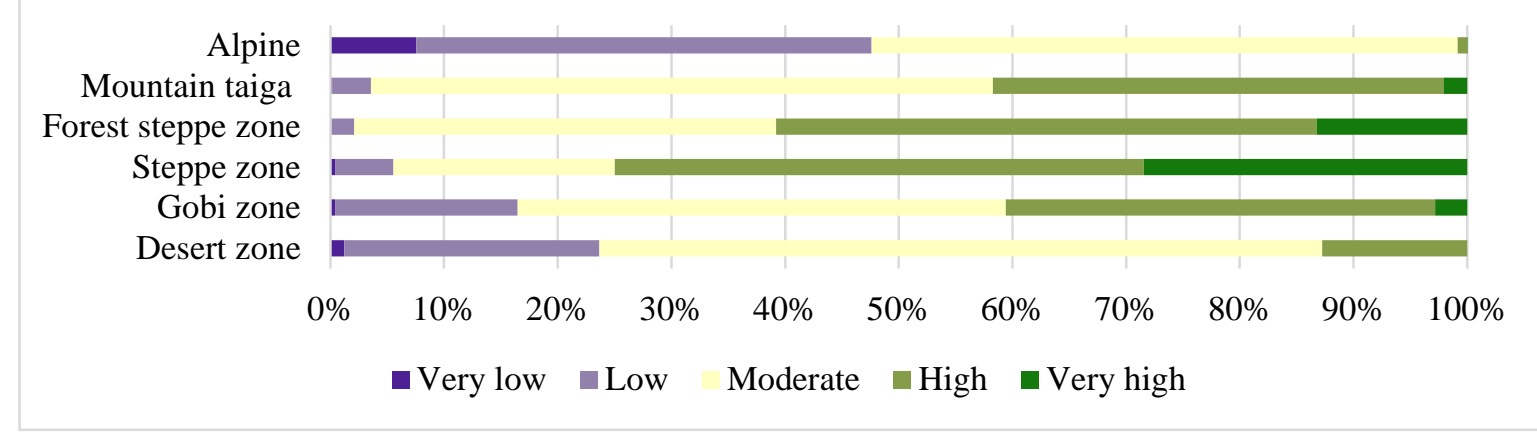

Figure 15. Assessment of the eco-geomorphological potential of Mongolia, (by natural belts and zones)

Following is a comparative result of the integrated assessment of eco-geomorphological potential of Mongolia by aimags and the capital city: In Darkhan-Uul, Orkhon, Dornod, Sukhbaatar, Govisumber, Khentii, Selenge, Tuv, Bulgan aimags and the capital city of Ulaanbaatar, the areas with very high or high ecological potential comprised of more than 85 per cent of the total territory of these aimags, while in Khuvsgul, Bayankhongor, Umnugovi, Khovd, Govi-Altai, and Bayan-Ulgii aimags, the areas with very high or high ecological potential accounted for less than 25 per cent of the total area of these aimags.

Table 13. Assessment of the eco-geomorphological potential of Mongolia, (by aimags)

\begin{tabular}{|c|c|c|c|c|c|c|c|c|}
\hline \multirow{2}{*}{$\begin{array}{c}\text { Aimags } \\
\text { (Provinces), } \\
\text { and Capital } \\
\text { city }\end{array}$} & \multirow{2}{*}{$\begin{array}{c}\text { Area of } \\
\text { aimags and } \\
\text { capital city } \\
\text { sq.km }\end{array}$} & \multicolumn{5}{|c|}{$\begin{array}{l}\text { Of which: Area for each evaluation } \\
\text { level, in percent }\end{array}$} & \multirow{2}{*}{ 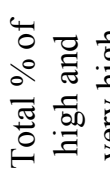 } & \multirow{2}{*}{ 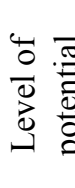 } \\
\hline & & $\begin{array}{l}\text { Very } \\
\text { low }\end{array}$ & Low & $\begin{array}{l}\text { Mod } \\
\text { erate }\end{array}$ & High & $\begin{array}{l}\text { Very } \\
\text { high }\end{array}$ & & \\
\hline \multicolumn{9}{|c|}{ Result of the eco-geomorphological potential of Mongolia } \\
\hline Arkhangai & 55313.8 & 0.1 & 4.1 & 44.9 & 50.2 & 0.7 & 50.9 & 14 \\
\hline Bayankhongor & 115977.8 & 1.2 & 24.8 & 57.6 & 16.4 & 0.0 & 16.4 & 18 \\
\hline Bayan-Ulgii & 45704.9 & 7.5 & 39.0 & 52.3 & 1.2 & 0.0 & 1.2 & 22 \\
\hline Bulgan & 48733.0 & 0.0 & 0.0 & 14.4 & 79.0 & 6.6 & 85.6 & 10 \\
\hline Darkhan-Uul & 3275.0 & 0.0 & 0.0 & 0.0 & 57.4 & 42.6 & 100.0 & 1 \\
\hline Dornod & 123597.4 & 0.0 & 0.0 & 0.0 & 38.1 & 61.9 & 100.0 & 1 \\
\hline Dornogovi & 109472.3 & 0.0 & 2.0 & 29.7 & 61.5 & 6.7 & 68.3 & 11 \\
\hline Dundgovi & 74690.3 & 0.0 & 0.6 & 35.2 & 63.5 & 0.7 & 64.1 & 12 \\
\hline Govi-Altai & 141447.7 & 2.4 & 40.0 & 53.0 & 4.6 & 0.0 & 4.6 & 21 \\
\hline Govisumber & 5541.8 & 0.0 & 0.0 & 0.5 & 68.7 & 30.8 & 99.5 & 5 \\
\hline Khentii & 80325.1 & 0.0 & 0.0 & 3.1 & 55.8 & 41.1 & 96.9 & 6 \\
\hline Khovd & 76060.4 & 3.4 & 37.7 & 49.6 & 9.4 & 0.0 & 9.4 & 20 \\
\hline Khuvsgul & 100628.8 & 0.3 & 8.4 & 65.3 & 25.5 & 0.4 & 25.9 & 17 \\
\hline Orkhon & 844.0 & 0.0 & 0.0 & 0.0 & 61.8 & 38.2 & 100.0 & 1 \\
\hline Selenge & 41152.6 & 0.0 & 0.0 & 7.2 & 58.0 & 34.8 & 92.8 & 7 \\
\hline Sukhbaatar & 82287.2 & 0.0 & 0.0 & 0.1 & 45.5 & 54.4 & 99.9 & 4 \\
\hline Tuv & 74042.4 & 0.0 & 0.1 & 11.8 & 75.8 & 12.3 & 88.1 & 8 \\
\hline Ulaanbaatar & 4704.4 & 0.0 & 0.0 & 13.8 & 72.9 & 13.3 & 86.2 & 9 \\
\hline Umnugovi & 165380.5 & 0.2 & 11.8 & 73.2 & 14.8 & 0.0 & 14.8 & 19 \\
\hline$U v s$ & 69585.4 & 0.2 & 13.0 & 52.8 & 32.1 & 1.9 & 34.0 & 15 \\
\hline Uvurkhangai & 62895.3 & 0.0 & 3.1 & 37.2 & 59.2 & 0.5 & 59.7 & 13 \\
\hline Zavkhan & 82455.7 & 0.2 & 7.5 & 63.4 & 28.5 & 0.4 & 28.9 & 16 \\
\hline
\end{tabular}




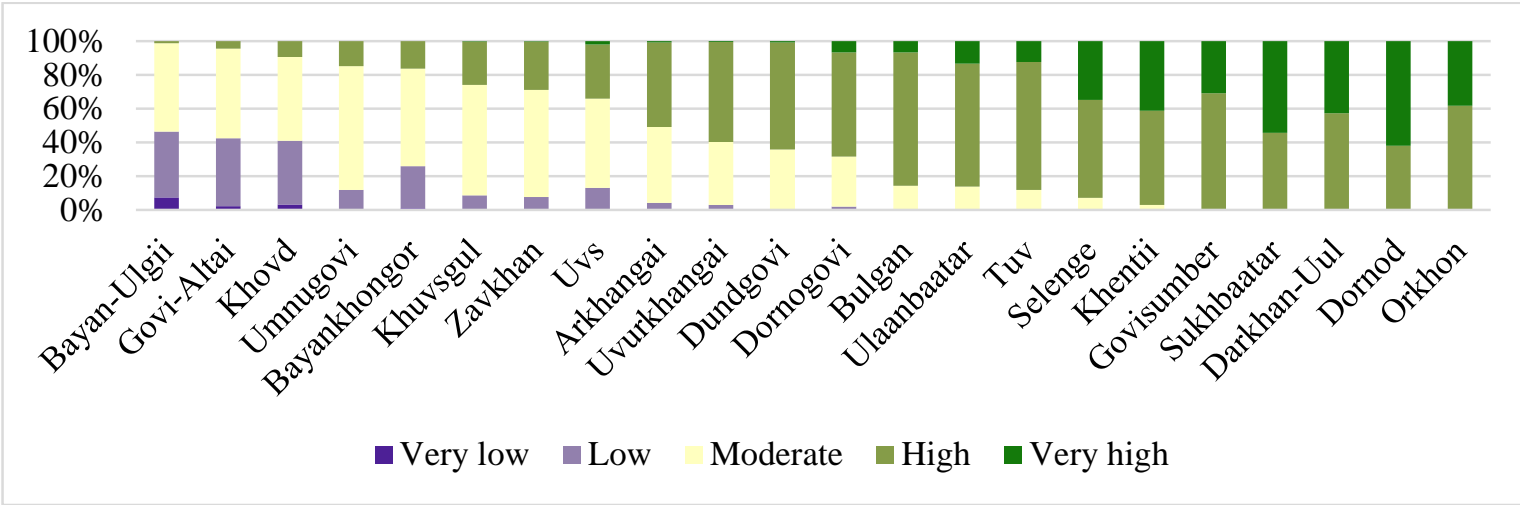

Figure 16. Assessment of eco-geomorphological potential of Mongolia, (by aimags)

\section{CONCLUSIONS}

The spatial resolutions of the thematic layers used as evaluation criteria by default in Mongolia were developed at $500 \mathrm{~m}$, depending on the repeatability and availability of the data. In the eco-geomorphological assessment, the ecological potential was assessed as very low, low, moderate, high, very high, taking into account the population, livestock, and agriculture, also as a follower of the relief factors and the climatic factors that have the greatest influence on the surface changes and modern processes that take place on them. The relief plays various direct and indirect ecological roles. Rising elevation above the sea level creates microclimate zones, such as lower air pressure, oxygen deficiency, and reduction of air temperature, excessive solar radiation, and creation of strong winds, so relief factors have a significant impact on our daily lives.

In Mongolia, steppe and forest-steppe zones are high eco-geomorphological potential zones, whereas landscapes with low and very low eco-geomorphological potential are common in the high mountain belts, gobi, and desert zones. Landscape with very high and high eco-geomorphological potential cover more than 85 per cent of the total territory of Darkhan-Uul, Orkhon, Dornod, Sukhbaatar, Govi Sumber, Khentii, Selenge, Tuv, and Bulgan aimags and the capital city of Ulaanbaatar, which are located in the abovementioned zones with high potential.
Moreover, these aimags have a large population and urban concentration, and also these are the main regions for livestock and agriculture development. The findings of this study are significant by summarizing geomorphological or relief factors with climatic factors affecting them, and we recommend that further research work should concentrate on enhancing the resolution of climate data for doing large scale research in a smaller area. We have developed the map of eco-geomorphological potential in Mongolia by default, and the map can be applied as a basis for urban planning and agriculture, especially for the planning of livestock and agricultural areas.

Acknowledgments. This research work was carried out within the framework of research project "Assessment of the landscapeecological potential of Mongolia natural zones" that was funded by the Science and Technology Foundation of Mongolia and implemented by the Institute of Geography and Geoecology, Mongolian Academy of Sciences during the years 2017-2019. We would like to thank the project leader, and all colleagues at the Division of Physical Geography, Institute of Geography and Geoecology, Mongolian Academy of Sciences, who provided direct and indirect assistance in the successful implementation of the research, and for the invaluable suggestions at the initial stage of the research 


\section{REFERENCES}

1. Makarov, V. Z., Chichagov, V. P. and Bulanov, S. A. 2013. Geomorphology and Cartography (XXXIII plenary session of geomorphological commission RAS). Geomorphology, (1), pp.121-125. Saratov.

2. Soboleva, N. P. and Yazikov, N. P. 2010. Landscape Science: Textbook. Tomsk State University, Tomsk.

3. Evseeva, N. S., 2017. Environmental geomorphology: Hazardous natural processes. Tomsk State University, Tomsk

4. Faculty of G eography, Lomonosov Moscow State University. 2015. Environmental geomorphology: new directions. Moscow.

5. Administration of Land Affairs, Geodesy and Cartography. 2019. Report on unified land fund. Ulaanbaatar.

6. https://earthexplorer.usgs.gov/.

7. http://hydro.iis.u-tokyo.ac.jp/ yamadai/MERIT_DEM/.

8. Evseeva, N. S. and Osintseva, N. V., 2013. Environmental geomorphology: Education guidance, Tomsk State University, Tomsk.

9. Kara, Y. and Köne, A. Ç., 2012. The analytic hierarchy process (AHP) approach for assessment of regional environmental sustainability. In Evidence for Sustainable Development: Berlin Conference on the Human Dimensions of Global Environmental Change (pp. 5-6).

10. Krujalin, V. I., 2001. Environmental geomorphology. Moscow.

11. Jigj S., 1975. The main features of the depressions in Mongolia. Ulaanbaatar.

12. Jigj S, 1979. The basic issues in engineering geography of Mongolia. Ulaanbaatar.
13. Deev S. V., Козлова A. E., Markelov A. V., Markelov D. A., Medvedev A. A., Mineeva N. Ja., 2011. Creating a cartographic ecological and geomorphological digital model of the territory of the city of Moscow. Russian Academy of Sciences, Institute of geography, Moscow.

14. Law of Mongolia. 1993. The Law on legal status of cities and settlements. Ulaanbaatar.

15. National Statistics Office. 2019. Mongolian Statistical Information Service. Ulaanbaatar.

16. Yamamura, N., Fujita, N. and Maekawa, A. eds., 2012. The Mongolian ecosystem network: environmental issues under climate and social changes. Springer Science \& Business Media. Ulaanbaatar.

17. Bazargur D, 2013. The science of Ecological Geography. Institute of Geography, Mongolian Academy of Sciences, Ulaanbaatar

18. Nyamkhuu M, 2015. Considering the surface features in the estimation of pasture use and its load. Khureltogoot, Ulaanbaatar

19. Boldbaatar N., Sainbuyan B., Bazargur D., 2017. Using Satellite data in the science of Ecological Geography of Mongolia. Khureltogoot, Ulaanbaatar

20. Otgonbayar, M., Atzberger, C., Chambers, J., Amarsaikhan, D., Böck, S. And Tsogtbayar, J., 2017. Land Suitability Evaluation for Agricultural Cropland in Mongolia Using the Spatial MCDM Method and AHP Based GIS. Journal of Geoscience and Environment Protection. 